\title{
A experiência na elaboração de recomendações para a diretriz diagnóstica de mesotelioma maligno de pleura
}

Palavras-chave: mesotelioma maligno de pleura, diretriz (PCDT), diagnóstico, imunohistoquímica, GRADE.

Introdução: O mesotelioma maligno pleural (MMP) é um tipo de câncer raro, com prognóstico reservado - mais de $80 \%$ de óbitos no primeiro ano. 0 diagnóstico correto é um desafio, pois o padrão histológico pode ser confundido com outros tipos de câncer na pleura, como o adenocarcinoma. A combinação de marcadores de imunohistoquímica positivos e negativos (reativos para outros tipos de câncer) pode ser uma ferramenta importante no diagnóstico diferencial. Na elaboração da diretriz diagnóstica, se buscou identificar os marcadores com maior acurácia diagnóstica e definir um painel de combinações para elaboração de uma recomendação.

Método: Uma revisão sistemática com metanálise foi realizada para síntese dos resultados de sensibilidade e especificidade dos marcadores selecionados. A análise da qualidade do corpo da evidência e a definição da direção e força da recomendação foram realizadas pela metodologia GRADE. No painel de especialistas, foram avaliadas as evidências de diferentes combinações de marcadores em três cenários de probabilidades pré-teste, definidas como as prevalências $(P)$ de MMP em possíveis grupos de pacientes-alvo para investigação imunohistoquímica $(1,0 \%, 3,0 \%$ e $20,0 \%)$.

Resultados: Um total de 22 marcadores (14 positivos e oito negativos) foram identificados, sendo selecionados quatro positivos e quatro negativos com maior sensibilidade e especificidade para MMP. Após a avaliação do resultado das combinações dos oito marcadores, foi recomendado um painel com pelo menos dois marcadores positivos e dois negativos para 0 diagnóstico de MMP, em função das maiores probabilidades pós-teste nos cenários de maior prevalência: $93,1 \%$ a $98,7 \%(P=3,0 \%) ; 99,2 \%$ a $99,8 \%$ $(P=20,0 \%)$.

Conclusão: Os especialistas definiram por unanimidade uma recomendação a favor do painel de imuno-histoquímica, sendo forte no cenário de maior prevalência e fraca na prevalência intermediária. Neste contexto, a necessidade de informações sobre exposição ocupacional/ambiental ao amianto e suspeita clínico-radiológica deve ser enfatizada. 


\section{The experience of recommendations development for the malignant pleural mesothelioma diagnostic guidelines}

Keywords: malignant pleural mesothelioma, guideline, diagnostic, immunohistochemical, GRADE.

Introduction: Malignant pleural mesothelioma (MPM) is a rare cancer with a poor prognosis - more than $80 \%$ of deaths in the first year. Correct diagnosis is challenging due to a histological pattern misclassification towards other types of pleural cancer, such as adenocarcinoma. The combination of immunohistochemical markers, positive and negative (reactive for other cancers), can be an important tool in differential diagnosis. During the MPM diagnostic guideline elaboration, we sought to identify the markers with greater diagnostic accuracy and to define a panel of immunohistochemical markers combinations to elaborate a recommendation.

Method: A systematic review with meta-analysis was performed to synthesize the sensitivity and specificity results of the selected markers. The quality evidence analysis and definition of direction and strength of the recommendation were performed through the GRADE methodology. In the expert panel, evidence of different combinations of markers was evaluated in three pre-test probability scenarios, defined as the prevalence (P) of MPM in possible target groups for immunohistochemical investigation $(1.0 \%$, $3.0 \%$ and $20.0 \%)$.

Results: A total of 22 markers (14 positives and eight negatives) were identified, and four positives and four negatives with higher sensitivity and specificity for MPM were selected. After evaluation of the eight markers combinations, a panel with at least two positive and two negative markers was recommended for the diagnosis of MPM, due to the higher post-test probabilities in the most prevalent scenarios: $93.1 \%$ to $98.7 \%$ ( $P=3.0 \%$ ); $99.2 \%$ to $99.8 \%(P=20.0 \%)$.

Conclusion: The experts unanimously defined a diagnostic recommendation in favor of the immunohistochemistry panel, strong for the higher prevalence scenario and weak for the intermediate prevalence. In this context, the need for information on occupational/environmental exposure to asbestos and clinical-radiological suspicion should be emphasized. 